\title{
Performance of the double-cross tomato hybrids from a partial diallel
}

\section{Desempenho de híbridos duplos de tomate de um dialelo parcial}

\author{
Rafael de Matos ${ }^{1}\left(\mathbb{D}\right.$, Juliano Tadeu Vilela de Resende ${ }^{2}$ (D) André Ricardo Zeist ${ }^{3}$ (iD), \\ Lígia Erpen-Dalla Corte ${ }^{2}$ (D) Paulo Roberto Da-Silva1 ${ }^{(\mathbb{D})}$, Douglas Mariani Zeffa ${ }^{4 *}$
}

\author{
${ }^{1}$ Universidade Estadual do Centro Oeste/UNICENTRO, Guarapuava, PR, Brasil \\ ¿Universidade Estadual de Londrina/UEL, Londrina, PR, Brasil \\ ${ }^{3}$ Universidade do Oeste Paulista/UNOESTE, Presidente Prudente, SP, Brasil \\ ${ }^{4}$ Universidade Estadual de Maringá/UEM, Maringá, PR, Brasil \\ *Corresponding author: douglas.mz@hotmail.com \\ Received in October 26, 2020 and approved in February 28, 2021
}

\begin{abstract}
Knowledge of the combining ability of genotypes, genetic diversity, and heterosis play the paramount role in obtaining double-cross hybrids with high productivity. This study was aimed at evaluating these parameters in tomato genotypes using partial diallel crosses among the commercial single-cross hybrids, which verified the possibility of using double-cross hybrids for commercial purposes. Tomato genotypes included 15 double-cross hybrids, their genitors, and two commercial genotypes as checks. Of the fifteen double-cross hybrids of tomato, two crosses exhibited superiority, such as Aguamiel $\times$ Compack and Dominador $\times$ Compack, mainly for the total and commercial fruit yields. The phenotypic expression of the trait is controlled by the genes with non-additive effects, whereas the genes with additive effects account for the genotypes of fruit mass, horizontal diameter, vertical diameter, and bunch insertion height. Regarding the genetic diversity, molecular analyses pointed out polymorphism for 79 percent of the evaluated loci evidencing a high genetic variability among the genitors. The heterosis values were low for most of the crosses, except for Forty $\times$ Plutão that represented 107 percent of heterosis for the total fruit yield. As compared with the commercial checks, the diallel cross generated superior quality hybrids, which inferred the possibility of obtaining double-cross hybrids of tomato with significant heterosis.
\end{abstract}

Index terms: Solanum lycopersicum; ISSR; molecular markers; plant breeding; heterosis.

\begin{abstract}
RESUMO
O conhecimento da capacidade de combinação entre genótipos, diversidade genética e heterose desempenha um papel fundamental na obtenção de híbridos duplos com potencial produtivo. Este estudo teve como objetivo avaliar esses parâmetros em genótipos de tomate por meio de um cruzamento dialélico balanceado entre híbridos simples comerciais, gerando híbridos duplos. Os genótipos de tomate incluíram 15 híbridos duplos, seus genitores e dois genótipos comerciais como testemunhas. Dos 15 híbridos duplos, dois cruzamentos exibiram superioridade, Aguamiel × Compack e Dominador × Compack, principalmente em relação à produção de frutos comerciais. Para essa caracteristica, genes com efeito não aditivo controlam sua expressão. Para massa do fruto, diâmetro horizontal, diâmetro vertical e altura de inserção do cacho, genes com efeito aditivo são responsáveis pela sua expressão genotípica. Em relação à diversidade genética, as análises moleculares indicaram polimorfismo para $79 \%$ dos locos avaliados, evidenciando a alta variabilidade genética dos genitores. Os valores de heterose foram baixos para a maioria dos cruzamentos, exceto para a combinação Quarenta $\times$ Plutão, que apresentou heterose de $107 \%$ para a produção total de frutos. O cruzamento dialélico gerou combinações híbridas com desempenho superior em relação às testemunhas comerciais, sugerindo a possibilidade de obter híbridos duplos de tomate com heterose significante.
\end{abstract}

Termos para indexação: Solanum lycopersicum; ISSR; marcadores moleculares; melhoramento de plantas; heterose.

\section{INTRODUCTION}

The adoption of hybrid cultivars greatly boosted tomato production worldwide. As compared to the open-pollinated cultivars, hybrids with higher yields have features that contribute to better agronomic performances (Noonari et al., 2015; Rosa et al., 2019). These advantages depend on the traits of the genitors, which result from heterosis for desirable traits, such as yield potential and fruit quality. Thus, a crucial step to developing superior quality hybrids involves the selection of the best genitors.

The use of double-cross tomato hybrids is still unusual among the farmers, probably because of the scarcity of information on the performance of traits of 
interest, such as yield and post-harvest components. However, investigations confirmed that the doublecross hybrids showed rearrangement events leading to the genetic variability and, consequently, the phenotypic differences between the yield traits (Costa et al., 2016).

The selection of genitors to develop hybrids requires knowledge of their agronomic features. However, depending only on the phenotype (performance per se), a choice is insufficient to guarantee the obtention of progenies showing transgressive segregants. Consequently, any genetic progress that occurred in the progenies of these crosses might be random or difficult to repeat (Ashakina; Rahman; Kabir, 2016; Figueiredo et al., 2017). The genotypes were selected for the crossings might show desirable agronomic traits along with an expressive positive combining ability to produce favorable combinations at high frequency (Mieulet et al., 2018).

Although the tomato hybrids available on the market contain high genetic potential concerning agronomic traits, little or no information about the genetics of these materials is available as most of them are developed by the private companies that do not provide these data (Schreinemachers et al., 2017). This situation can often limit the use of these genotypes in breeding programs (Foolad; Panthee, 2012). An alternative to overcome this barrier is to perform planned crossings between simple-cross hybrids to obtain double-cross hybrids. The knowledge of agronomic performance and genetic variability of double-cross hybrids may contribute to the understanding of the genetic bases of the commercial cultivars (Farooq et al., 2012). Furthermore, double-cross hybrids are little explored in the tomato segment, possibly due to higher production costs and greater unevenness of its fruits. Nonetheless, heterosis, as well as the incorporation of genes responsible for disease resistance, precocity, fruit quality, and yield in the new genotypes, may surpass these disadvantages (Ashakina; Rahman; Kabir, 2016).

One of the most used methodologies to determine the best hybrid combinations is the diallel analysis, which allows the selection of the most promising genitors depending on their combining abilities (Kumar et al., 2018; Kaushik; Dhaliwal, 2018; Gomes et al., 2021). The association of diallel crosses and molecular markers along with the morphoagronomic ones provides information on variability, genetic distance, and phenotypic patterns of the genotypes under field conditions, whose data are essential for driving the choice of genitors in breeding programs (Bhandari et al., 2019). In this study, the single-cross hybrids and the resulting double-cross hybrids were evaluated for their combining abilities and heterotic values using morpho-agronomic traits as well as for genetic variations using inter-simple sequence repetition (ISSR) molecular markers. Besides, this research verified the possibility of using double-cross hybrids for commercial purposes.

\section{MATERIAL AND METHODS}

\section{Obtention and evaluation of double-cross hybrids}

The experiments were carried out at the experimental area and the Genetics and Biotechnology Laboratory of the State University of the Central-West, Guarapuava, Brazil ( $25^{\circ} 22^{\prime} 59^{\prime \prime S}$ and $51^{\circ} 29^{\prime} 43^{\prime \prime} \mathrm{W}$ at $1,100 \mathrm{~m}$ of altitude). The climatic condition of this region is classified as $\mathrm{Cfb}$ (Peel; Finlayson; Mcmahon, 2007), and the soil type is Dystroferric Red Latosol (Santos et al., 2013).

For the crosses, six simple-cross tomato hybrids exhibiting indeterminate growth were used: Pietra TM (Sakata Seeds Sudamérica ${ }^{\circledR}$ ), Compack ${ }^{\text {TM }}$ (Monsoy ${ }^{\circledR}$ ), Forty TM $\left(\right.$ Syngenta $\left.^{\circledR}\right)$, Dominador $\left(\right.$ Agristar $\left.^{\circledR}\right)$ with saladtype fruits; Aguamiel TM (Vilmorin Brazil ${ }^{\circledR}$ ), Plutão TM (Blueseeds ${ }^{\mathbb{R}}$ ) with Italian type fruits. Fifteen double-cross hybrids were selected: (1) Campack $\times$ Pietra, (2) Forty $\times$ Pietra, (3) Forty $\times$ Compack, (4) Dominator $\times$ Pietra, (5) Dominator $\times$ Compack, (6) Dominator $\times$ Forty, (7) Aguamiel $\times$ Pietra, (8) Aguamiel $\times$ Compack, (9) Aguamiel $\times$ Forty, (10) Aguamiel $\times$ Dominator, (11) Plutão $\times$ Pietra, (12) Plutão $\times$ Compack, (13) Plutão $\times$ Forty, (14) Plutão $\times$ Dominator and (15) Plutão $\times$ Aguamiel.

The double-cross hybrids were evaluated in a balanced diallel with their respective genitors using Griffing's model II (Griffing, 1956): $Y_{i j}=m+g_{i}+g_{j}+s_{i j}$ $+e_{i j}$, where $Y_{i j}$ is the value of the hybrid combination of the genitors, $i$ and $j ; m$ is the average effects of a specific trait; $g_{i}$ and $g_{i}$ are the effects of the general combining ability of genitors, $i$ and $j$; $s_{i j}$ is the effect of the specific combining ability of $i j$, and $e_{i j}$ is the experimental error associated with the crossing $i j$.

The balanced diallel included six simple-cross commercial hybrids of tomato as genitors, and their fifteen derived double-cross experimental $\mathrm{F}_{1}$ hybrids (totaling 21 genotypes). Two commercial genotypes were added as checks: salad-type $\mathrm{F}_{1}$ Alambra $^{\mathrm{TM}}$ (Clause ${ }^{\circledR}$ ) and Italian type Pizzadoro ${ }^{\mathrm{TM}}\left(\right.$ Nunhems $\left.^{\circledR}\right)$.

The hybrids were sown in trays at first, and when the plantlets presented 4-5 expanded leaves, 
they were transplanted to the field. The planting lines were mulched, and the soil was fertilized by applying $78 \mathrm{~kg}$ of $\mathrm{N} \mathrm{ha}^{-1}, 460 \mathrm{~kg}$ of $\mathrm{P}_{2} \mathrm{O}_{5} \mathrm{ha}^{-1}$, and $400 \mathrm{~kg}$ of $\mathrm{K}_{2} \mathrm{O} \mathrm{ha}^{-1}$. Additional fertilizers were applied during the plant cycle via fertigation using $1.34 \mathrm{~g} \mathrm{~L}^{-1}$ of $\mathrm{PG}$ mix $^{\mathrm{TM}}$ (14-16-18) from Yara ${ }^{\circledR}$ twice a week. The plants were conducted with two stems in vertical tutoring with tape and were irrigated by dripping. Moreover, the disease and pest control measures were performed with the recommended products for the culture alternating the active principles.

A randomized complete block design was used for twenty-three genotypes in four replications, totaling ninety-two plots. Each experimental unit was composed of 18 plants, which were arranged in double rows with the spacing of $0.3 \mathrm{~m} \times 0.5 \mathrm{~m} \times 1.10 \mathrm{~m}$. The evaluated yield components and biometric features of the fruits included total yield (TY) and commercial yield (CY); average fruit mass (AFM), vertical diameter (VD), horizontal diameter (HD), the height of the first bunch (HFB) and stem scar diameter (SSD).

\section{Estimates of general combining ability (GCA) and specific combining ability (SCA)}

The combining ability of the genitors was measured by the $\operatorname{GCA}\left(\hat{g}_{\mathrm{i}}\right)$ and $\operatorname{SCA}\left(\hat{\mathrm{s}}_{\mathrm{ii}}\right.$ and $\left.\hat{\mathrm{s}}_{\mathrm{ij}}\right)$ (Liu et al., 2020). Once a genitor was crossed with the others and then the average performance of that genitor was estimated in terms of GCA, which represented the additive effects of the alleles. The SCA was determined by a specific combination of two genitors, whose progeny performances were either above or below the expectations and solely based on the GCA values of both the genitors (Nizio et al., 2008).

\section{Heterosis based on the genitors' averages}

Heterosis $(H)$ was calculated for the 15 doublecross hybrids by the following equation: $\mathrm{H}=\left[\mathrm{F}_{1}-\left(\mathrm{P}_{1}+\right.\right.$ $\left.\mathrm{P}_{2}\right) / 2$ ], where $\mathrm{F}_{1}=$ average of the first progenies from the crosses (double-cross hybrids); $\mathrm{P}_{1}=$ average of the first genitors; and P2 = average of the second genitors. Average values of the seven traits related to the fruits were used to calculate $H$ included TY, CY, AFM, VD, HD, HFB, and SCD.

\section{Molecular characterization of the genitors}

For molecular characterization, leaflets from the six genitors were collected and immediately frozen in liquid nitrogen at first. Then DNA extraction was performed according to Sharma, Mishra and Misra (2008). Moreover, the DNA amplification reactions via PCR (polymerase chain reaction) were performed with the help of seven ISSR primers (Table 1). For PCR, the reaction components were prepared into a final volume of $12.5 \mu \mathrm{L}$ containing 20 ng of DNA, $1 \times$ PCR buffer, $0.2 \mu \mathrm{M}$ of each primer, $200 \mu \mathrm{M}$ of dNTPs, $1.5 \mathrm{mM}$ of $\mathrm{MgCl}_{2}$, and $1 \mathrm{U}$ of Taq DNA Polymerase. The thermal cycler was programmed for the initial denaturation at $94{ }^{\circ} \mathrm{C}$ for $5 \mathrm{~min}$, followed by 35 cycles of denaturation at $94^{\circ} \mathrm{C}$ for $45 \mathrm{~s}$, annealing at annealing temperature (Table 1 ) for $45 \mathrm{~s}$, and extension at $72{ }^{\circ} \mathrm{C}$ for $90 \mathrm{~s}$ along with the final step of extension at $72{ }^{\circ} \mathrm{C}$ for $5 \mathrm{~min}$.

Table 1: List of the seven ISSR primers used to estimate genetic variability among the six genotypes of the $F_{1}$ commercial tomato hybrids.

\begin{tabular}{ccc}
\hline Primer & Sequence $5^{\prime}-3^{\prime}$ & $\begin{array}{c}\text { Annealing } \\
\text { temperature }\left({ }^{\circ} \mathrm{C}\right)\end{array}$ \\
\hline UBC 807 & $(\mathrm{AG})_{8} \mathrm{~T}$ & 52 \\
UBC 808 & $(\mathrm{AG})_{8} \mathrm{C}$ & 50 \\
UBC 809 & $(\mathrm{AT})_{8} \mathrm{~T}$ & 55 \\
UBC 815 & $(\mathrm{CT})_{8} \mathrm{G}$ & 53 \\
UBC 835 & $(\mathrm{AG})_{8} \mathrm{YC}^{1}$ & 54 \\
UBC 836 & $(\mathrm{AG})_{8} \mathrm{YA}^{1}$ & 53 \\
UBC 864 & $(\mathrm{ATG})_{6}$ & 50 \\
\hline${ }^{1} \mathrm{Y}=(\mathrm{C}, \mathrm{T})$. & &
\end{tabular}

The amplification products were separated by agarose gel (1.8 percent) electrophoresis and stained with ethidium bromide $\left(0.5 \mu \mathrm{g} \mathrm{mL}^{-1}\right)$. In order to determine the sizes of the amplified fragments, a DNA ladder of $100 \mathrm{bp}$ was used. The fragments were visualized under UV light and then photo-documented by a digital system. The profiles of those ISSR markers were scored for presence (1) and absence (0) of the fragments in order to create a binary matrix for calculating the Jaccard similarity coefficient using NTSYSpc 2.1 software (Rohlf, 1992). The average similarity between the individuals was obtained by dividing the sum of the similarities by the number of pair-by-pair combinations obtained.

\section{Statistical analysis}

The analysis of variance (ANOVA), general combining ability (GCA), specific combining ability (SCA), heterosis $(H)$, and Scott-Knott (Scott; Knott, 1974) tests were performed using the software Genes ${ }^{\circledR}$ (Cruz, 2013). 


\section{RESULTS AND DISCUSSION}

\section{Statistical components}

The F-test in ANOVA showed statistical differences for yield components and morpho-agronomic traits $(p$ $<0.01$ ) (Table 2). The mean squares of the treatments were also found to be significant by the F-test $(p<0.01)$ for the evaluated traits $(p<0.05)$, showing genetic variations in the treated ones. The low variation coefficients (5.4 to 14.02 percent) demonstrated good experimental precision and indicated that the uncontrollable environmental variations barely affected the traits (Table 2). The obtained averages of the traits were grouped according to their significance, and the treatments were arranged in three distinct groups after minimizing variations within and maximizing variations among the groups (Table 3).

The decomposition of sum squares of the treatments into general combining ability $\left(\hat{\mathrm{g}}_{\mathrm{i}}\right)$ and specific combining ability $\left(\hat{\mathrm{s}}_{\mathrm{ij}}\right)$ represented significant results for most of the evaluated traits indicating both the additive and nonadditive gene effects that contributed to the phenotypic expressions of those traits (Table 2).

A diallel crossing system involving highperformance materials, such as simple-cross hybrids, requires special attention to the genetic traits involved and how the progenies inherit them. In this research, the variations in the genetic parameters were similar to the previous studies using partial diallel by Andrade et al. (2014) and Figueiredo et al. (2017), where the additive and non-additive effects of the genes act on the phenotypic expressions that could be spotted during the evaluation of the quadratic components of traits.

The calculated values demonstrated that for average fruit masses, vertical diameter, horizontal diameter, and height of the first bunch, the GCA estimates $\left(\hat{\mathrm{g}}_{\mathrm{i}}\right)$ were higher than the SCA estimates $\left(\hat{\mathrm{s}}_{\mathrm{ij}}\right)$, indicating the roles of the additive gene effects on the expression of these traits. The estimates showed superiority in specific combining ability $\left(\hat{\mathrm{s}}_{\mathrm{ij}}\right)$ to the general combining ability $\left(\hat{\mathrm{g}}_{\mathrm{i}}\right)$ for the total and commercial yields suggesting how the non-additive effects of the genes act more pronouncedly on the phenotypic expressions of these traits. However, when the GCA $\left(\hat{\mathrm{g}}_{\mathrm{i}}\right)$ and $\mathrm{SCA}\left(\hat{\mathrm{s}}_{\mathrm{ij}}\right)$ estimates showed similar values, the additive and non-additive effects were found to be equally important for the gene expression of a given trait, which was observed for the stem scar diameter trait (Table 2).

During the evaluation of combining ability of tomato lines of the varietal groups, such as salad-type (determined), Santa Cruz (determined and indeterminate), and Italian (indeterminate); Andrade et al. (2014) identified divergences of the GCA ( $\hat{\mathrm{g} i}$ ) and SCA (sij) among the groups and also of the total yield and average fruit mass. According to these authors, SCA (sij) showed non-additive gene effects for these traits, whereas the effects of the relationship between length and diameter (responsible for the greater elongated shape of Italian tomatoes) were observed to be significant for the GCA ( $\hat{g} i)$ and SCA ( $\hat{s} \mathrm{ij}$ ) values. Hence, they determined that the genes with additive and non-additive effects played a role in phenotypic expressions, mainly the ones acting with additive effects.

Table 2: Summary of the diallel analyses for general combining ability (GCA, $\left.\hat{g}_{i}\right)$ and specific combining ability $\left(\mathrm{SCA}, \hat{\mathrm{S}}_{\mathrm{ij}}\right)$ of yield components and biometric features of the fruits from double-cross tomato hybrids.

\begin{tabular}{|c|c|c|c|c|c|c|c|c|}
\hline $\begin{array}{l}\text { Source of } \\
\text { variation }\end{array}$ & DF & $\begin{array}{c}\text { TY } \\
(\mathrm{t} \mathrm{ha-1})\end{array}$ & $\begin{array}{c}C Y \\
\left(t \mathrm{ha}^{-1}\right)\end{array}$ & $\begin{array}{c}\text { AFM } \\
\left(\text { g plant }^{-1}\right)\end{array}$ & $\begin{array}{c}\mathrm{HD} \\
(\mathrm{mm})\end{array}$ & $\begin{array}{l}\text { VD } \\
(\mathrm{mm})\end{array}$ & $\begin{array}{l}\text { HFB } \\
(\mathrm{cm})\end{array}$ & $\begin{array}{l}\text { SSD } \\
(\mathrm{mm})\end{array}$ \\
\hline Block & 2 & 88.10 & 93.53 & 27.92 & 8.70 & 0.56 & 12.26 & 5.34 \\
\hline Treatment & 20 & 714.91 ** & $701.27 * *$ & $2.509 .05^{\star *}$ & $188.83^{* *}$ & $66.38 * *$ & $29.37 *$ & $27.88^{* *}$ \\
\hline GCA & 5 & $1.811 .66^{* *}$ & $1.785 .99 * *$ & $8408.30 * *$ & $692.99 * *$ & $219.32 * *$ & $66.75^{\star *}$ & $80.98 * *$ \\
\hline SCA & 15 & $349.33^{* *}$ & $339.65^{* *}$ & $542.63^{\text {ns }}$ & $20.76^{\text {ns }}$ & $15.39^{\text {ns }}$ & $16.93^{\text {ns }}$ & $10.17^{* *}$ \\
\hline Error & 40 & 53.48 & 68.39 & 419.93 & 15.16 & 25.33 & 12.44 & 1.30 \\
\hline \multicolumn{2}{|c|}{$\mathrm{QC}$ of GCA } & 73.25 & 71.56 & 332.84 & 28.24 & 8.08 & 2.26 & 3.32 \\
\hline \multicolumn{2}{|c|}{ QC of SCA } & 98.61 & 90.42 & 40.98 & 1.86 & -3.31 & 1.49 & 2.95 \\
\hline Means & - & 63.37 & 58.96 & 160.96 & 67.82 & 62.53 & 46.74 & 12.93 \\
\hline CV (\%) & - & 11.53 & 14.02 & 12.73 & 5.74 & 8.04 & 7.55 & 8.82 \\
\hline
\end{tabular}

$\mathrm{ns} ; * *$ and * non-significant, significant by the $\mathrm{F}$ test $(p<0.01)$ and $(p<0.05)$, respectively.

DF: degrees of freedom; TY: total yield; CY: commercial yield; AFM: average fruit mass; HD: horizontal diameter; VD: vertical diameter; HFB: high of the first bunch; SSD: stem scar diameter; QC: quadratic component; CV: coefficient of variation. 
Table 3: Yield components and morpho-agronomic traits of the fruits from genitors, simple-cross, and doublecross hybrids.

\begin{tabular}{|c|c|c|c|c|c|c|c|}
\hline Genotypes & TY $\left(\right.$ tha $\left.^{-1}\right)$ & CY $\left(\right.$ tha $\left.^{-1}\right)$ & AFM (g/fruit) & $\mathrm{HD}(\mathrm{mm})$ & $\mathrm{VD}(\mathrm{mm})$ & $\mathrm{HFB}(\mathrm{cm})$ & $\mathrm{SSD}(\mathrm{mm})$ \\
\hline Compack $\times$ Pietra & $56.14 \mathrm{c}$ & $43.73 \mathrm{~b}$ & $191.55 \mathrm{a}$ & $76.72 \mathrm{a}$ & $57.38 \mathrm{~b}$ & $45.93 \mathrm{~b}$ & $14.24 \mathrm{c}$ \\
\hline Forty $\times$ Pietra & $73.90 \mathrm{~b}$ & $71.11 \mathrm{a}$ & $205.02 \mathrm{a}$ & 77.09 a & $61.16 \mathrm{~b}$ & $48.91 \mathrm{a}$ & $16.03 \mathrm{~b}$ \\
\hline Forty $\times$ Compack & $54.58 c$ & $53.84 \mathrm{~b}$ & $187.05 \mathrm{a}$ & $76.51 \mathrm{a}$ & $65.72 \mathrm{a}$ & $49.11 \mathrm{a}$ & $14.45 \mathrm{c}$ \\
\hline Dominador $\times$ Pietra & $67.83 \mathrm{~b}$ & 66.27 a & $167.19 b$ & $71.48 \mathrm{~b}$ & $56.41 \mathrm{~b}$ & $46.54 \mathrm{~b}$ & $14.83 \mathrm{~b}$ \\
\hline Dominador $\times$ Compack & $85.19 \mathrm{a}$ & $83.03 \mathrm{a}$ & 205.96 a & $78.41 \mathrm{a}$ & $60.14 \mathrm{~b}$ & $48.25 \mathrm{a}$ & $15.95 b$ \\
\hline Dominador $\times$ Forty & $66.78 \mathrm{~b}$ & 65.88 a & $165.29 \mathrm{~b}$ & $69.31 \mathrm{~b}$ & $59.00 \mathrm{~b}$ & $51.43 a$ & $14.93 \mathrm{~b}$ \\
\hline Aguamiel $\times$ Pietra & $76.38 \mathrm{~b}$ & $71.82 \mathrm{a}$ & $162.02 b$ & $65.09 c$ & 59.82 b & $44.27 \mathrm{~b}$ & $13.61 \mathrm{c}$ \\
\hline Aguamiel × Compack & $86.92 \mathrm{a}$ & 76.78 a & $159.75 b$ & $69.06 \mathrm{~b}$ & 64.35 a & $47.61 \mathrm{a}$ & $11.18 d$ \\
\hline Aguamiel $\times$ Forty & $67.67 b$ & $60.89 a$ & $138.81 \mathrm{c}$ & $64.34 \mathrm{c}$ & $61.66 b$ & $50.23 a$ & $13.08 \mathrm{c}$ \\
\hline Aguamiel $\times$ Dominador & $70.23 \mathrm{~b}$ & $65.86 \mathrm{a}$ & $139.33 c$ & $63.83 c$ & 63.68 a & $45.40 \mathrm{~b}$ & $9.45 \mathrm{e}$ \\
\hline Plutão × Pietra & $58.65 \mathrm{c}$ & $48.14 b$ & $153.28 \mathrm{c}$ & $65.91 \mathrm{c}$ & $63.53 a$ & $43.11 \mathrm{~b}$ & $14.22 \mathrm{c}$ \\
\hline Plutão × Compack & $51.20 \mathrm{c}$ & $47.11 \mathrm{~b}$ & 144.65 c & $62.89 \mathrm{c}$ & 66.57 a & $44.88 \mathrm{~b}$ & $12.25 \mathrm{c}$ \\
\hline Plutão × Forty & $61.88 c$ & $53.79 b$ & $149.16 \mathrm{c}$ & $63.80 \mathrm{c}$ & 68.53 a & $42.27 \mathrm{~b}$ & $11.27 d$ \\
\hline Plutão × Dominador & $52.00 \mathrm{c}$ & $47.84 \mathrm{~b}$ & $146.18 \mathrm{c}$ & $61.95 c$ & $63.23 \mathrm{a}$ & $41.84 \mathrm{~b}$ & $8.59 \mathrm{e}$ \\
\hline Plutão × Aguamiel & $56.00 \mathrm{c}$ & $49.96 \mathrm{~b}$ & $100.31 d$ & $50.68 d$ & $71.83 a$ & $42.50 \mathrm{~b}$ & $7.75 \mathrm{e}$ \\
\hline Pietra & $58.36 \mathrm{c}$ & $56.21 \mathrm{~b}$ & $165.29 \mathrm{~b}$ & $71.44 \mathrm{~b}$ & $55.07 \mathrm{~b}$ & $50.60 a$ & $15.13 b$ \\
\hline Compack & $68.93 \mathrm{~b}$ & $65.45 \mathrm{a}$ & $188.20 \mathrm{a}$ & 75.62 a & 57.96 b & $45.00 \mathrm{~b}$ & $13.92 \mathrm{c}$ \\
\hline Forty & $29.44 \mathrm{~d}$ & $27.20 \mathrm{c}$ & $178.47 \mathrm{~b}$ & $74.01 \mathrm{a}$ & $59.08 \mathrm{~b}$ & $49.19 a$ & $13.75 \mathrm{c}$ \\
\hline Dominador & $74.07 \mathrm{~b}$ & $72.46 \mathrm{a}$ & $192.00 \mathrm{a}$ & 73.92 a & 59.24 & $50.50 \mathrm{a}$ & $19.55 \mathrm{a}$ \\
\hline Aguamiel & $84.61 \mathrm{a}$ & $80.83 a$ & $135.01 \mathrm{c}$ & $61.70 \mathrm{c}$ & 69.65 a & $50.41 a$ & $7.36 \mathrm{e}$ \\
\hline Plutão & $30.21 \mathrm{~d}$ & 29.87 c & $105.64 d$ & $50.67 d$ & 69.26 a & $43.63 \mathrm{~b}$ & $10.11 d$ \\
\hline Alambra & $61.57 c$ & $57.49 b$ & $166.36 \mathrm{~b}$ & $71.10 \mathrm{~b}$ & 53.37 b & $57.67 \mathrm{a}$ & $13.83 \mathrm{c}$ \\
\hline Pizzadoro & $51.61 \mathrm{c}$ & $48.93 \mathrm{~b}$ & $110.49 d$ & $54.82 \mathrm{~d}$ & $68.55 a$ & $25.16 \mathrm{c}$ & $8.80 \mathrm{e}$ \\
\hline Means & 62.78 & 58.45 & 159.00 & 67.40 & 62.39 & 46.28 & 12.79 \\
\hline
\end{tabular}

*Means followed by the same letter in the column belong to the same group according to the Scott-Knott test ( $p<0.05)$.

TY: total yield; CY: commercial yield; AFM: average fruit mass; VD: vertical diameter; HD: horizontal diameter; HFB: high of the first bunch; SSD: stem scar diameter;

The simple-cross hybrids, Dominador and Compack, showed positive values for all the evaluated traits, except for the vertical fruit diameter, which was expected for the inherent traits of this varietal group. However, Pádua et al. (2010) found predominant additive effects for the total yield and average fruit mass in tomatoes with determined growth. Figueiredo et al. (2017) observed a predominance of additive effects in the genotypes for average fruit mass, fruit shape, and length-width ratio traits of fruits for the industry. The non-additive effects were found to be superior for total and commercial yields and stem scar diameter, which also occurred in the present study.
As expected, no high or moderate heterosis $(H)$ estimates were observed for the traits evaluated in most of the double-cross hybrids, except for the $F_{1}$ of Forty $\times$ Pietra and Plutão $\times$ Forty for the total yield and commercial yield, respectively (Table 4).

Regarding $H$, low results were obtained for yield, and biometric traits as per the evaluation in the doublecross tomato hybrids. The hybrid combinations involving genitors with high genetic distance or less degree of kinship had more pronounced heterotic effects, which could be seen in the combination Forty $\times$ Plutão, whose $H$ was 107 percent for the total yield. The combining ability involving Forty, except with Compack, was positive, 
indicating their greater general combining ability, which was reflected in its $H$ values. The Plutão hybrid had a higher specific combining ability since positive heterosis effects appeared in only two of the five combinations with this genitor.

Notably, the total yield and commercial yield of tomato fruits had incomplete dominance, and thus, significant values of $H$ were unexpected. The absence of positive values could directly affect the inheritance mechanisms of fruit size since the dominance was absent or incomplete to a lesser extent.

Dominance over a trait, reducing its values, justified the negative $H$ resulting from a hybrid performance as compared to the average of its genitors. In the occurrence of loci with positive and negative dominance, the effects could be canceled out, and the $H$ might not occur. $H$ was, therefore, the sum of the effects, favorable to the vigor of heterozygous loci among the progenies (Falconer; Mackay, 1996), and considering the interactions of dominance and/or overdominance, it was not used to increase the phenotypic value. However, it would be emphasized that, when these interactions occurred, the generations of the hybrids configured the best strategy to get adapted.

Dominance complementation explained the classical $H$ in maize (McMullen et al., 2009), and as per the evidence, epistasis played an important role in rice $H$ (Yu et al., 1997). According to Krieger, Lippman and Zamir (2010), a noteworthy percentage of putative mutants over the dominant ones suggested that the $H$ through mutant heterozygosity might be a general phenomenon for the plants and other organisms. Screening of large sets of heterozygous mutants in other models and crop species could yield additional examples of single-gene heterosis and provide innovative germplasms for plant breeding.
Heterosis might result from the tuned activities of dosage-dependent regulatory systems controlling signaling cascades and transcriptional networks (Birchler; Yao; Chudalayandi, 2007). Results provided a notable example of single-gene overdominance for tomato yielding and offered empirical evidence, which proved that rather than being caused by allelic interactions, subtle changes in gene dosage could lead to overdominance. This overdominance depended on opposing the flowering signals from SFT (Single Flower Truss) and SP (Self Pruning), whose relationship had been proposed to be critical for the overall plant growth (Shalit et al., 2009). It had been hypothesized that $\mathrm{sft} /+$ heterosis was based on the altered dosage of functional SFT protein within each modular sympodial unit (Krieger; Lippman; Zamir 2010).

\section{Yield components and morpho-agronomic traits of single and double-cross tomato hybrids}

For total yield, the $\mathrm{F}_{1}$ double-cross hybrids of Aguamiel $\times$ Compack $\left(86.92 \mathrm{t} \mathrm{ha}^{-1}\right)$, and Dominador $\times$ Compack $\left(85.19 \mathrm{t} \mathrm{ha}^{-1}\right)$ were superior to the others. Among all the evaluated genitors, the simple-cross commercial tomato hybrid, Aguamiel (84.61 t ha ${ }^{-1}$ ) was the most productive. As for commercial yield, the double-cross hybrids, Forty $\times$ Pietra, Dominador $\times$ Pietra, Dominador $\times$ Compack, Dominador $\times$ Forty, Aguamiel $\times$ Pietra, Aguamiel $\times$ Compack, Aguamiel $\times$ Forty, and Aguamiel $\times$ Dominador obtained averages superior to the check genotypes, Alambra $F_{1}$ (salad varietal group) and Pizzadoro (Italian varietal group).

The superiority observed among the double-cross hybrids as compared to the checks used in the study were in responses to the capacity of combination between them that explored the $H$ and the genetic divergence.

Table 4: Estimates of general combining ability ( $\left.\hat{\mathrm{g}}_{\mathrm{i}}\right)$ for total yield (TY), commercial yield (CY), average fruit mass (AFM), vertical diameter (VD), and horizontal diameter (DH) of tomato fruits from the hybrid genitors.

\begin{tabular}{cccccc}
\hline \multirow{2}{*}{ Genitor } & \multicolumn{5}{c}{$\hat{\mathrm{g}}_{\mathrm{i}}$} \\
\cline { 2 - 5 } & $\mathrm{TY}\left(\mathrm{t} \mathrm{ha}^{-1}\right)$ & $\mathrm{CY}\left(\mathrm{t} \mathrm{ha}^{-1}\right)$ & $\mathrm{AFM}(\mathrm{g} /$ fruit $)$ & $\mathrm{HD}(\mathrm{mm})$ & $\mathrm{VD}(\mathrm{mm})$ \\
\hline Pietra $^{\mathrm{TM}}$ & 0.74 & 0.10 & 10.36 & 3.04 & -3.66 \\
Compack $^{\mathrm{TM}}$ & 3.52 & 2.83 & 17.33 & 5.00 & -0.95 \\
Forty $^{\mathrm{TM}}$ & -7.49 & -6.59 & 9.44 & 3.03 & -0.44 \\
Dominador $^{\mathrm{TM}}$ & 5.81 & 7.64 & 10.15 & 2.25 & -2.10 \\
Aguamiel $^{\mathrm{TM}}$ & 10.34 & 9.28 & -19.56 & -4.80 & 2.86 \\
Plutão $^{\mathrm{TM}}$ & -12.93 & -13.26 & -27.73 & -8.53 & 4.30 \\
\hline
\end{tabular}


The manifestation of $H$ could be observed not only in the yield components but also in the morpho-physiological traits that, in turn, could result in a gain in productivity and fruit quality (Borém; Miranda, 2009). As per the observed values, the double-cross hybrids produced after the crossings were found to be superior and characterized by their greater genetic divergence (Figure 1) because according to Falconer and Mackay (1996), genetic distance was found to be positively correlated to heterosis.

The single-cross hybrids included Aguamiel, Compack, and Dominador, which did not differ from the double-cross hybrids in greatest commercial yield, but they were superior to the commercial hybrids, Alambra $F_{1}$ and Pizzadoro. The genitors, Forty and Plutão displayed the worst performance for this variable (Table 3). As per some studies, the superiority of double-cross hybrids, concerning the simple-cross and triple-cross ones, was observed along with the inferiority of the double-cross hybrids for the yield components as compared to the single-cross hybrids (Ahmad; Quamruzzaman; Islam, 2011; Farooq, 2012; Ashakina; Rahman; Kabir, 2016).

The double-cross $\mathrm{F}_{1}$ hybrids, Compack $\times$ Pietra $(191.55 \mathrm{~g} /$ fruit), Forty $\times$ Pietra $(205.02 \mathrm{~g}$ /fruit), Forty $\times$ Compack (187.05 g/fruit), and Dominador $\times$ Compack $(205.96 \mathrm{~g} /$ fruit), showed higher average fruit mass. Among the genitors, Dominador (188.20 g/fruit) and Compack $(192.00 \mathrm{~g} /$ fruit) produced fruits with a greater average mass surpassing the others, including the check genotypes of Alambra $F_{1}$ and Pizzadoro. The genotypes with the lowest average values for this trait were found in the double-cross $\mathrm{F}_{1}$ hybrids, Plutão $\times$ Aguamiel; genitor, Plutão; and check, Pizzadoro (Table 3).

The double-cross $\mathrm{F}_{1}$ hybrids, Compack $\times$ Pietra $(76.72 \mathrm{~mm})$, Forty $\times$ Pietra $(77.09 \mathrm{~mm})$, Forty $\times$ Compack $(76.51 \mathrm{~mm})$, and Dominador $\times$ Compack $(78.41 \mathrm{~mm})$ along with the genitors, Compack (75.62 mm), Forty (74.01 $\mathrm{mm}$ ), and Dominador $(73.92 \mathrm{~mm})$ displayed the largest vertical fruit diameter.

Regarding the horizontal diameter of fruits, the genotypes with superior results were the double-cross $\mathrm{F}_{1}$ hybrids, Forty $\times$ Pietra $(48.91 \mathrm{~mm})$, Forty $\times$ Compack $(49.11 \mathrm{~mm})$, Dominator $\times$ Compack $(48.25 \mathrm{~mm})$, Dominator $\times$ Forty $(51.43 \mathrm{~mm})$, Aguamiel $\times$ Compack $(47.61 \mathrm{~mm})$ and Aguamiel $\times$ Forty $(50.23 \mathrm{~mm})$ as well as the simple-cross $\mathrm{F}_{1}$ hybrids, Pietra $(50.60 \mathrm{~mm})$, Forty $(49.19 \mathrm{~mm})$, Dominator $(50.50 \mathrm{~mm})$, Aguamiel (50.41 $\mathrm{mm}$ ), and Alambra (57.67 mm) (Table 3).

The lowest height of the first bunch was observed in the check genotype, Pizzadoro, which did not lead to the yield increase. Regarding the stem scar diameter,
$\mathrm{F}_{1}$ of the double-cross hybrids, Aguamiel $\times$ Dominador (9.45 mm), Plutão $\times$ Dominador $(8.59 \mathrm{~mm})$, and Plutão $\times$ Aguamiel $(7.75 \mathrm{~mm})$ along with the genitor, Aguamiel (7.36 $\mathrm{mm})$, and the check genotype, Pizzadoro (8.80 $\mathrm{mm}$ ) were found to have the smallest diameters among all (Table 3). According to the modern classification of commercial fruits, the vertical diameter was a crucial trait as it determined the fruit format for selection (Tamta; Singh, 2018). For this trait, practically all the crossings involving the genitors, Aguamiel and Plutão (Italian type), obtained the superior averages along with the check genotype, Pizzadoro (Italian type).

Of the 15 double-cross tomato hybrids evaluated, two $F_{1}$ crosses resulted in superior traits, Aguamiel $\times$ Compack and Dominator $\times$ Compack. Unlike $H$, extreme phenotypes, generated by transgressive segregation were found to be inheritable and stable. It could occur even if more than two known loci had common alleles at the region of crossing, which implied that there might be a similar genetic basis between the genitors (Koide et al., 2019).

\section{General combining ability (GCA) of genitors}

For the total and commercial yields of fruits, the genitors, Pietra, Compack, Dominador and Aguamiel showed positive values of the GCA $\left(\hat{\mathrm{g}}_{\mathrm{i}}\right)$, respectively, and the highest numbers were obtained for Dominator (5.81/7.64 $\left.\mathrm{t} \mathrm{ha}^{-1}\right)$ and Aguamiel (10.34/9.28 $\left.\mathrm{t} \mathrm{ha}^{-1}\right)$. For the same variables, the lowest values $(-12.93 /-13.26 \mathrm{t}$ $\mathrm{ha}^{-1}$, respectively) were estimated for the commercial hybrid, Plutão.

Depending on the GCA $\left(\hat{\mathrm{g}}_{\mathrm{i}}\right)$ of the genitors, greater amplitudes were observed for the total $\left(23.27 \mathrm{t} \mathrm{ha}^{-1}\right)$ and commercial $\left(22.54 \mathrm{t} \mathrm{ha}^{-1}\right)$ yields for Aguamiel and Plutão hybrids (Table 3) when compared to the general average of the experiment; which was $63.37 \mathrm{t} \mathrm{ha}^{-1}$ for the total yield and $58.96 \mathrm{t} \mathrm{ha}^{-1}$ for the commercial yield. For the simple-cross hybrids of the salad-type, the main difference occurred for the genotype Forty, which showed negatives values, whereas the simple-cross hybrids, Pietra, Compack, Dominador, and Aguamiel showed positive values (Table 4).

Concerning average fruit mass, the GCA values $\left(\hat{g}_{\mathrm{i}}\right)$ showed an amplitude of $45.06 \mathrm{~g}$ of fruits $^{-1}$ : from $-27.73 \mathrm{~g}$ of fruits ${ }^{-1}$ for the Italian type Plutão to $17.33 \mathrm{~g}$ of fruits ${ }^{-1}$ for the salad-type Compack. This feature was directly associated with the yield, and thus, all the saladtype tomatoes (Pietra, Compack, Forty, and Dominator) obtained positive values, whereas the hybrids, Aguamiel and Plutão (Italian type), resulted in negative values (-19.56 g/fruits and -27.73 g/fruits, respectively) (Table 4). 


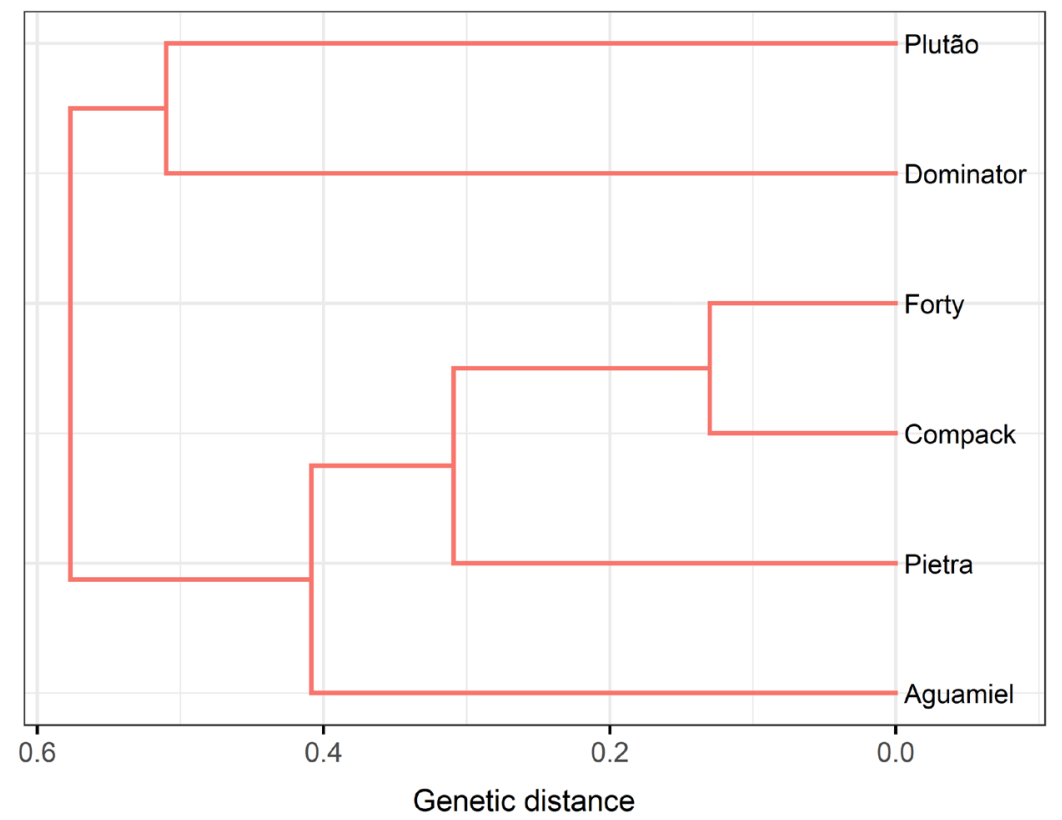

Figure 1: Dendrogram obtained by Ward's method using the Jaccard similarity coefficient depending on seven ISSR primers identified in six tomato genitors.

As for vertical diameter, the salad-type hybrids were more promising in producing larger fruits with an average amplitude of $13.53 \mathrm{~mm}$. The commercial hybrids, Compack, Pietra, Forty, and Dominador showed positive GCA $\left(\hat{\mathrm{g}}_{\mathrm{j}}\right)$, while for Aguamiel and Plutão, these values were negative, evidencing the reduced vertical diameter of their fruits. The horizontal diameter of the Italian type tomatoes behaved almost inversely to the salad-type ones. The latter represented negative values of GCA $\left(\hat{g}_{i}\right)$ as expected since it was an anatomic feature of the group. The Aguamiel and Plutão (Italian type) tomatoes expressed positive values of GCA $\left(\hat{g}_{i}\right)$ for this trait (Table 4).

The Forty hybrid showed better performance at the crosses as a genitor since it resulted in superior double-cross hybrids as compared to the other hybrid combinations and the check genotypes. The genetic divergence of Forty, in relation to the other genotypes, explained this behavior. The only exception came from the Plutão hybrid with negative GCA (ĝi) values for the total and commercial yields and vertical fruit diameter.

\section{Specific combining ability $\left(\hat{\mathrm{s}}_{\mathrm{ij}}\right)$ (SCA)}

Of the six simple-cross hybrids used as genitors, Pietra, Forty, Dominador, and Aguamiel showed negative $\mathrm{SCA}\left(\hat{\mathrm{s}}_{\mathrm{ii}}\right)$ estimates indicating genetic divergence between them with low specific combining ability for the total and commercial yields (Table 5). The simple-cross hybrid, Forty had the most negative value for its total yield $\left(-18.94 \mathrm{tha}^{-1}\right)$. Forty was the most divergent among all the genotypes studied, which supposedly contributed to the high values of $H$ in the crosses it participated.

Some crosses promoted fruit segregation for three different types of commercial tomatoes (Salad, Santa Cruz and Italian). This feature could be interesting for small farmers as it allowed simultaneous exploration of more than one market segment from a single crop. Studies of genes that controlled the tomato fruit shape found a monogenic inheritance with complete dominance for the round shape over the elongated shape, but the pleiotropic effects and mutations in diverse gene loci were not discarded (Tanksley, 2004). The shape of the tomato fruit resulted from the action of several gene loci, which could act in different ways, making it difficult to elucidate its inheritance. The cross that obtained the best results was Dominador $\times$ Compack, as it presented salad-type fruits with a commercial pattern, which were important factors in the consumers' choice.

The crosses that obtained positive values for the SCA $\left(\hat{\mathrm{s}}_{\mathrm{ij}}\right)$ in all the evaluated traits were Plutão $\times$ Forty, Forty $\times$ Pietra, and Dominador $\times$ Compack (Table 5). With the negative estimates of SCA $\left(\hat{s}_{\mathrm{ij}}\right)$, the crosses Compack $\times$ Pietra and Aguamiel $\times$ Dominador, presented negative 


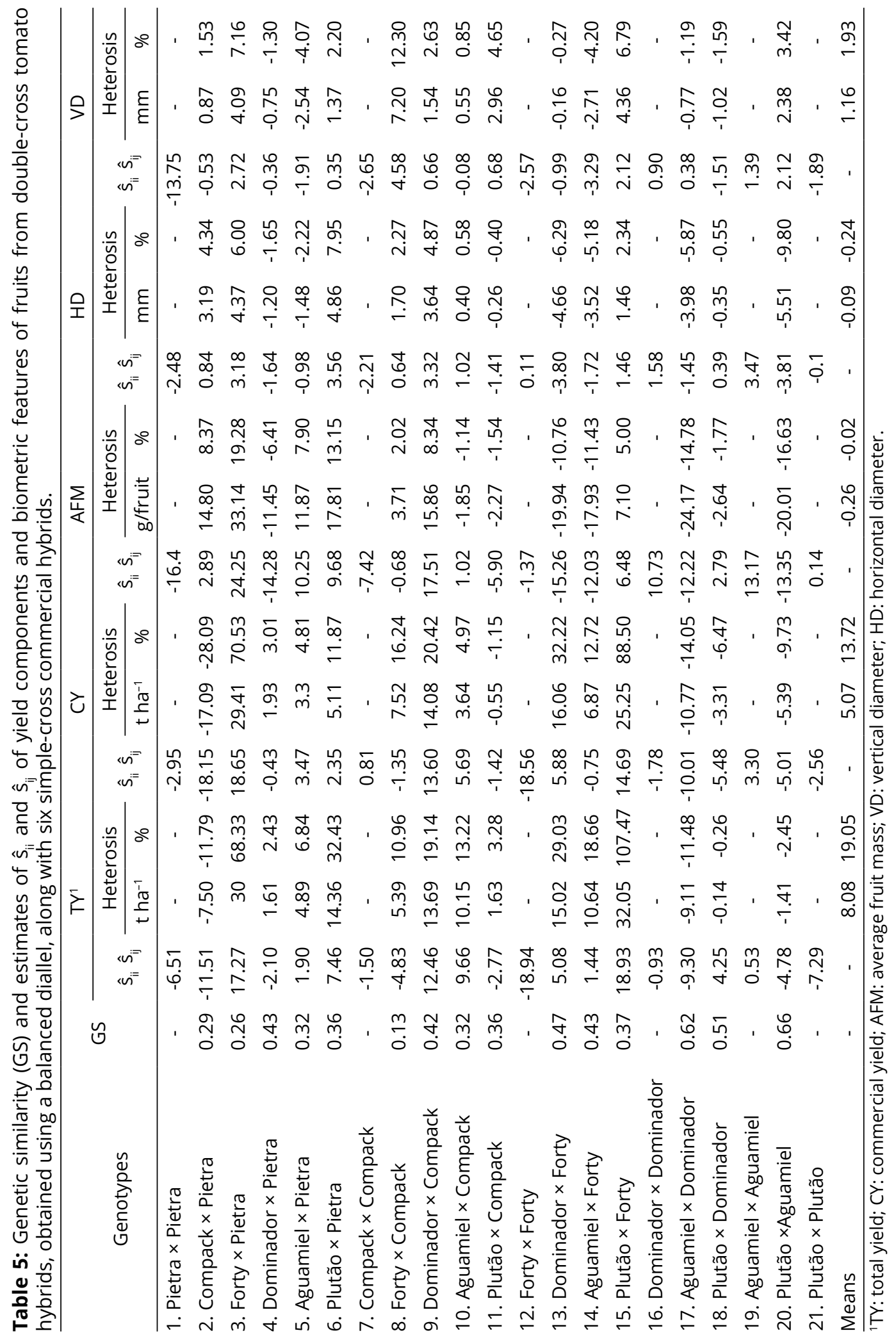


values for all the evaluated traits, except for horizontal diameter (Table 5). The crossing estimates between the hybrids, Forty and Pietra were the highest for the total $\left(17.27 \mathrm{t} \mathrm{ha}^{-1}\right)$ and commercial $\left(18.65 \mathrm{t} \mathrm{ha}^{-1}\right)$ yields (Table $5)$, showing the greater divergence between these two simple-cross hybrids.

The most positive SCA $\left(\hat{\mathrm{s}}_{\mathrm{ij}}\right)$ estimates for the average fruit mass were obtained for the double-cross hybrid originated from Forty $\times$ Pietra $(24.25 \mathrm{~g} /$ fruit $)$ and Dominador $\times$ Compack (17.51 g/fruit). For the same trait, the most negative estimates were observed in the doublecross hybrids, coming from Compack $\times$ Pietra $(-16.4 \mathrm{~g} /$ fruit), Dominator $\times$ Forty $(-15.26 \mathrm{~g} /$ fruit $)$, and Plutão $\times$ Aguamiel $(-13.35 \mathrm{~g} /$ fruit). The crosses, Plutão $\times$ Pietra, Dominator $\times$ Compack, and Forty $\times$ Pietra resulted in the positive and high values of SCA $\left(\hat{s}_{\mathrm{ij}}\right)$, while for the crossings Plutão $\times$ Aguamiel and Dominator $\times$ Forty, the values were the most negative. The greatest fruit horizontal diameter was obtained from the hybrids Forty $\times$ Compack, Plutão $\times$ Forty, and Forty $\times$ Pietra. In contrast, the least effective crosses for this trait were Aguamiel $\times$ Forty and Forty $\times$ Compack (Table 5).

Five of the six simple-cross hybrids, used as the genitors, showed negative estimates of the SCA $\left(\hat{s}_{\mathrm{ii}}\right)$, indicating high genetic divergence between them for total and commercial yields, except for the commercial yield from Compack (Table 5). The hybrid genitor, Pietra showed negative SCA $\left(\hat{\mathrm{s}}_{\mathrm{ii}}\right)$ for all the evaluated traits. In order to obtain high-performing hybrids, the GCA ( $\hat{g} i)$ and SCA (ŝij) estimates along with the heterosis were positive and representative (Griffing, 1956). Thus, the general combining ability, as well as the specific one estimated in this research, might guide the choice of promising genitors and obtention of great hybrid combinations.

\section{Heterosis $(\mathrm{H})$}

The average $H$ observed in the double-cross hybrids for total and commercial yields were 19.5 percent $(8.08 \mathrm{t}$ $\left.\mathrm{ha}^{-1}\right)$ and 13.72 percent $\left(5.07 \mathrm{t} \mathrm{ha}^{-1}\right)$, respectively (Table 5). The estimate obtained by the variability existing within the diallel of double-cross hybrids, in relation to the genitors' average (single-cross $F_{1}$ hybrids), was observed for the crossing, Plutão $\times$ Forty with 107 percent of $H(32.05 \mathrm{t}$ $\left.\mathrm{ha}^{-1}\right)$ for the total yield and 88.5 percent of $H\left(25.5 \mathrm{tha}^{-1}\right)$ for the commercial yield. For Forty $\times$ Pietra, the $H$ for the total yield was 68.33 percent with an approximate gain of $30 \mathrm{t} \mathrm{ha}^{-1}$ fruits, and for commercial yield, the gain was $29.41 \mathrm{tha}^{-1}$ (70.5 percent $\left.H\right)$.

For the crossing, Compack $\times$ Pietra, the estimated negative $H$ values were -11.79 percent for the total yield $\left(-7.5 \mathrm{tha}^{-1}\right)$ and -28.09 percent for the commercial yield $\left(-17.09 \mathrm{t} \mathrm{ha}^{-1}\right)$. The negative $H$ value, obtained for the average fruit mass, was -0.02 percent $(-0.26 \mathrm{~g} /$ fruit $)$ and for the vertical fruit diameter, was -0.24 percent $(-0.09$ $\mathrm{mm}$ ), reinforcing that $H$ hardly appeared in the doublecross hybrids for these traits (Table 5).

\section{Genetic similarity between parents}

The seven ISSR primers used 59 amplified loci, out of which, 47 (79.66 percent) were polymorphic. The similarity between the genitors varied from 0.26 (Forty and Campack) to 0.66 (Plutão and Aguamiel), with an average similarity of 0.40 between all the genitors (Table 5). The Ward dendrogram has been shown in Figure 1.

As for the genetic variability accessed via molecular markers, the polymorphism of the 79 percent of evaluated loci showed that the hybrids used as genitors in this study were highly variable. When working with the dominant markers, the percentage of polymorphism could be used to estimate the genetic variability of a species. In a study with six tomato varieties using ISSR markers, the observed polymorphism was 56 percent (Ray, 2010). Aguilera et al. (2011) obtained an average of 36.80 percent of polymorphism for 96 tomato accessions. The results obtained in this study showed high genetic variability in the tomato hybrids evaluated, indicating the use of different genetic bases in their development.

The evaluation of genetic similarities between genitors, GCA, and SCA showed no correlation. The genetically closest genitors were Plutão and Aguamiel ( 0.66 similarities), whereas the most distant ones were Forty and Compack (0.13). However, interestingly, these combinations did not display the best or worst estimates of GCA and SCA, but a correlation between these variables had been reported for the simple-cross tomato hybrids. Figueiredo et al. (2016) identified that the less similar genitors were the ones, who had the best GCA and SCA estimates. Additionally, Mohamed et al. (2018) observed that the genitors with the lowest genetic similarity, identified by the ISSR markers, were the ones with the best performing hybrids.

The use of ISSR markers was determined to be inefficient in identifying the genitors for developing superior double-cross hybrids in tomatoes. However, during this research, $H$ showed moderate to low values in the double-cross hybrids for most of the evaluated traits. Although it did not prevent the adoption of double-cross tomato hybrids but was found to be crucial to define the economic viability. 
In the present research, two double-cross $F_{1}$ hybrids, Aguamiel $\times$ Compack and Dominador $\times$ Compack showed yield averages equivalent to that of the simplecross commercial hybrid Aguamiel, which was found to be the most productive in the trial. Additionally, these genotypes were observed as superior to $F_{1}$ Alambra, one of the most important salad-type and Pizzadoro, one of the most important Italian type hybrids in Brazil.

For total yield and commercial yield, the greatest divergence occurred due to the SCA $\left(\hat{\mathrm{s}}_{\mathrm{ij}}\right)$ showed that the phenotypic expressions were controlled by the actions of non-additive genes. As for average fruit mass, vertical diameter, horizontal diameter, and height of first bunch insertion, the phenotypic expressions were attributed to the GCA $\left(\hat{g}_{i}\right)$; and the genes with additive effects were observed to be responsible for the differences between genotypes. This research proved that additive and nonadditive genes act in the inheritance of these traits. Vekariya et al. (2019) also obtained equivalent results using diallel cross-system in tomatoes.

The genitors used, Pietra, Forty, Dominador, and Aguamiel showed low estimates of SCA $\left(\hat{\mathrm{s}}_{\mathrm{ij}}\right)$ along with the negative values for total and commercial yields proving genetic divergences for these traits in the chosen materials. The best crosses for the traits related to commercial fruit production and total production were captured from the genotypes with greater genetic divergences showing moderate effects of heterosis. Genetic divergence was found to be closely related to the GCA and SCA, in which the most divergent hybrids were the most promising on crosses. It confirmed that this was used to depend on the traits along with the genes with additive and non-additive effects that contributed to the performance of the double hybrids.

\section{CONCLUSIONS}

The recombination of genetic variability by diallel crosses was allowed to generate superior experimental genotypes as compared to the commercial genotypes, which proved the possibility to obtain double-cross tomato hybrids with promising commercial potential. All the genetic effects involved in the expression of the evaluated traits were evident from this study, which might further guide tomato breeding programs in the future.

\section{REFERENCES}

AGUILERA, J. G. et al. Variabilidade genética em tomate (Solanum lycopersicon Mill.) por marcadores ISSR.
Revista Brasileira de Ciências Agrárias, 6(2):243252, 2011.

AHMAD, S.; QUAMRUZZAMAN, A.; ISLAM, M. Estimate of heterosis in tomato (Solanum Lycopersicum L.). Bangladesh Journal of Agricultural Research, 36(3):521527, 2011.

ANDRADE, M. C. et al. Combining ability of tomato lines in saladette-type hybrids. Bragantia, 73(3):237-245, 2014.

ASHAKINA, A.; RAHMAN, W.; KABIR, L. Performance of single, double and three-way cross hybrids in tomato (Lycopersicon esculentum Mill.). Journal of Food, Agriculture and Environment, 14(1):71-77, 2016.

BHANDARI, H. R. et al. Efficiency of molecular diversity vs phenotypic diversity in attaining heterosis - A case study with tomato. International Journal of Bio-resource and Stress Management, 10(3):261-265, 2019.

BIRCHLER, J. A.; YAO, H.; CHUDALAYANDI, S. Biological consequences of dosage dependent gene regulatory systems. Biochimica et Biophysica Acta, 1769(5-6):422428, 2007.

BORÉM, A.; MIRANDA, G. V. Melhoramento de plantas. $5^{\mathrm{a}}$ Ed. Viçosa, Editora UFV, 2009. 529p.

COSTA, J. H. P. et al. Tomato second cycle hybrids as a source of genetic variability for fruit quality traits. Crop Breeding and Applied Biotechnology, 16(4):289-297, 2016.

CRUZ, C. D. GENES - A software package for analysis in experimental statistics and quantitative genetics. Acta Scientiarum Agrononomy, 35(3):271-276, 2013.

FALCONER, D. S.; MACKAY, T. F. C. Introduction to quantitative genetics. Essex. UK: Longman Group, 1996. 480p.

FAROOQ, A. M. et al. Development and comparative studies of double cross tomato hybrids. African Journal of Agriculture Research, 7(37):5259-5264, 2012.

FIGUEIREDO, A. S. T. et al. Genetic divergence among processing tomato hybrids and formation of new segregating populations. Ciência e Agrotecnologia, 41(3):279-287, 2017.

FIGUEIREDO, A. S. T. et al. Prediction of industrial tomato hybrids from agronomic traits and ISSR molecular markers. Genetics and Molecular Research, 15(2):113, 2016. 
FOOLAD, M. R.; PANTHEE, D. R. Marker-Assisted selection in tomato breeding. Critical Reviews in Plant Sciences, 31(2):93-123, 2012.

GOMES, G. P. et al. Diallel analysis of the morphoagronomic, phytochemical, and antioxidant traits in Capsicum baccatum var. pendulum. Horticulture, Environment, and Biotechnology, 1-12, 2021.

GRIFFING, B. A generalized treatment of the use of diallel crosses in quantitative inheritance. Heredity, 10:31-50, 1956.

JH, P. C. et al. Tomato second cycle hybrids as a source of genetic variability for fruit quality traits. Crop Breeding and Applied Biotechnology, 16(4):289-297, 2016.

KAUSHIK, P.; DHALIWAL, M. Diallel analysis for morphological and biochemical traits in tomato cultivated under the influence of tomato leaf curl virus. Agronomy, 8(8):153, 2018.

KOIDE, Y. et al. Genetic properties responsible for the transgressive segregation of days to heading in rice. G3: Genes, Genomes, Genetics, 9(5):1655-1662, 2019.

KRIEGER, U.; LIPPMAN, Z. B.; ZAMIR, D. The flowering gene single flower truss drives heterosis for yield in tomato. Nature Genetics, 42(5):459-63, 2010.

KUMAR, R. et al Combining ability and gene action studies of some post-harvest and nutritional quality traits in tomato (Solanum lycopersicum L). AgricINTERNATIONAL, 5(2):17-22, 2018.

LIU, J. et al. Exploring the molecular basis of heterosis for plant breeding. Journal of Integrative Plant Biology, 62(3):287-298, 2020.

MCMULLEN, M. D. et al. Genetic properties of the maize nested association mapping population. Science, 325:737-740, 2009.

MIEULET, D. et al. Unleashing meiotic crossovers in crops. Nature Plants. 4(12):1010-1016, 2018.

MOHAMED, M. F. et al. Phenotypic and molecular assessments of newly derived F4 recombinant lines of tomato. Indian Journal of Genetics, 78(4):487-495, 2018.

NIZIO, D. A. C. et al. Caracterização de genótipos de tomateiro resistentes a begomovírus por marcador molecular codominante ligado ao gene Ty-1. Pesquisa Agropecuária Brasileira, 43(12):1699-1705, 2008.
NOONARI, S. et al. Price plexibility and seasonal variations of major vegetables in sindh pakistan. Journal of Food Process and Technololy, 6(12):e1000524, 2015.

PÁDUA, T. R. P. et al. Capacidade combinatória de híbridos de tomateiro de crescimento determinado, resistentes a begomovirus e tospovirus. Pesquisa Agropecuária Brasileira. 45(8):818-825, 2010.

PEEL, M. C.; FINLAYSON, B. L.; MCMAHON, T. A. Updated world map of the Köppen-Geiger climate classification. Hydrology and Earth System Sciences, 4(2):439-473, 2007.

RAY, D. P. Molecular characterization of six released tomato varieties using inter simple sequence repeat markers. Indian Journal of Horticulture, 67(3):328-333, 2010.

ROHLF, F. J. Program numerical taxonomy and multivariate analysis system. Version 1.70, New York. 1992. Available in: <https://ntsyspc.software.informer.com/2.1/> Access in: March, 2, 2021.

ROSA, A. H. B. et al. Butterflies collected using malaise traps as useful bycatches for ecology and conservation. Journal of Threatened Taxa, 11(9):14235-14237, 2019.

SANTOS, H. G. et al. Sistema brasileiro de classificação de solos. 3a edição revista e ampliada. Brasília, DF: Embrapa, 2013. 353p.

SCHREINEMACHERS, P. et al. The contribution of international vegetable breeding to private seed companies in India. Genetic Resources and Crop Evolution, 64(5):1037-1049, 2017.

SCOTT, A. J.; KNOTT, M. A cluster analysis method for grouping means in the analysis of variance. Biometrics, 30:507-512, 1974.

SHALIT, A. et al. The flowering hormone florigen functions as a general systemic regulator of growth and termination. Proceedings of the National Academy of Sciences, 106(20):8392-8397, 2009.

SHARMA, K.; MISHRA, A. K.; MISRA, R. S. A simple and efficient method for extraction of genomic DNA from tropical tuber crops. African Journal of Biotechnology, 7(8):1018-1022, 2008.

TAMTA, S.; SINGH, J. P. Heterosis in tomato for growth and yield traits. International Journal of Vegetable Science, 24(2):169-179, 2018.

TANKSLEY, S. D. The genetic, developmental, and molecular bases of fruit size and shape variation in tomato. The Plant Cell, 16:S181-S189, 2004. 
VEKARIYA, T. et al. Combining ability analysis for yield and its components in tomato (Solanum lycopersicum L.). Acta Scientific Agriculture, 3(7):185-191, 2019.
YU, S. B. et al. Importance of epistasis as the genetic basis of heterosis in an elite rice hybrid. Proceedings of the National Academy of Sciences, 94(17):9226-9231, 1997. 